\title{
Ali A. Mazrui, IIIT, and the Muslim Experience in the United States of America
}

This editorial is dedicated to paying a tribute to Professor Ali A. Mazrui, who passed away in Binghamton, New York, on October 13, 2014. From 2009 (AJISS 26:1) until his passing, Professor Mazrui was the editor-in-chief for this journal. In years to come, we may consider dedicating a special issue to him and his general intellectual contributions. But for now, we present the following tribute penned by his friend and colleague, Professor Sulayman S. Nyang (Howard University, Washington, DC), as published in IIIT "Special Issue: Farewell Professor Ali Mazrui” (October 2014).

Professor Ali A. Mazrui, the celebrated scholar, author, and public intellectual from Kenya came, performed, and departed gracefully. Certainly, those who knew him well gladly fared him well, knowing beyond reasonable doubt that he had the nerve and the verve to represent both Islam and Africa faithfully and effectively. It is against this background that one can examine a profile of the man and his legacies within many domains in America, the Islamic world, and in the larger world.

Born on February 24, 1933, in Mombasa, Kenya, Professor Mazrui came out of an Afro-Arab ancestry that affected his life at home and overseas. As it is now well known, through the intervention of a British colonial governor who arranged a scholarship for him to study in England, Ali A. Mazrui completed his high school education at Huddersfield College before moving on to Manchester University, where he completed his first degree in political science with distinction. Upon graduation, he secured a fellowship to Columbia University, where he graduated with a Master degree in politics.

This introduction to a scholarship from the Rockefeller Foundation in New York was the beginning of a lifetime association with American and other think tanks and foundations around the world. From his association with Columbia University, Professor Mazrui was destined to develop multiple linkages with 
scholars, students, and administrators who are described elsewhere as members of the "twelve tribes of Washington." More on these links to Mazruiana below; let us complete this profile in courage and scholarship of the man from Mombassa. After his graduation from Columbia University he went to Oxford University, where he performed well and developed meaningful contacts with persons associated with foundations and think tanks in the West.

After receiving his doctorate, he secured a job at Makerere University. A school that was not available to him as an undergraduate was destined later to welcome him as a graduate from Oxford and then - over time - elevated him to the rank of full professor after several years from his association with that East African center of higher learning. Again, in developing this profile of Ali A. Mazrui and his involvement with centers of higher learning, think tanks, and Muslim organizations in the United States of America and beyond, let me add three more points before we embark on a serious discussion of his entanglements with Muslim pioneering think tanks such as the IIIT - on the one hand - and national, state, and local Islamic bodies across the country, on the other.

The first item on the agenda is Mazrui and his visions for Africa and Islam; the second deals with his ideas, aspirations, and activism between town and gown; and finally, his intimate involvement with the IIIT and its quest to make a big difference in projecting a distinctive and respectable affirmation of Muslim values and cultures around the world. This triangular metaphor is deployed ostensibly to highlight the man and his association with think tanks, scholars, and students around the globe.

Thus, in writing about Professor Ali A. Mazrui and his involvement with think tanks, we must pay closer attention to what he said or did during his lifetime on Earth. Based on data available to me from his books, essays, and personal conversations over the years, one could argue here that Mazrui saw that foundations and think tanks are part and parcel of our decision as human beings to bring about changes in our lives by harnessing our intellectual and material resources in the service of humanity and the natural order.

For this and other related reasons, Mazrui's view of the world cast him as prophetic in the classical sense of speaking to power in the face of social, economic, or political challenges. What is being said here is that, like other public intellectuals, Mazrui was definitely willing to deploy words as swords of moral power in the battle of wills between those in the 1 percent and the 99 percent. Truth be told, the man from Mombasa was willing to link himself with think tanks so long as their leaders were not going to impose their wills over him. People from the Ford Foundation and other intellectual outposts in the West were familiar with the man and his ideas. 
In writing about Professor Ali A. Mazrui and the think tanks, particularly the IIIT, several points need to be identified for clarification and understanding. First of all, how did Ali engage the founders and staff of the IIIT? To the best of my knowledge, Ali, who has been active in African and Islamic studies, was acquainted with the late Ismail Faruqi. Although I cannot identify precisely the date and occasion when the two gentlemen knew each other, however, I could assert categorically here that they started communicating and exchanging messages until the demise of the Palestinian-American colleague. Truth be told, Ali and Ismail met face-to-face in my presence at a conference organized by the Unificationalist movement held in Miami in the same year when former President Reagan defeated Jimmy Carter.

Both of them enjoyed the company of their older colleagues such as Dr. Seyyed Hossein Nasr, then at Temple University before relocating to George Washington University. The purpose of that conference was to assemble some of the best intellectuals in the world who were willing to give the benefit of the doubt to the unificationist drive to facilitate a dialogue between peoples from different religious and cultural traditions. In that gathering, scholars and activists such as Ali A. Mazrui of Kenya, Francis Abdullah Botchway from Ghana, John Mbiti of Kenya, Khurshid Ahmed of Pakistan, and many younger scholars like me conversed and interacted with others from other faith communities around the world. Ismail Faruqi was then the major Muslim partner, whose colleagues at Temple had already established the Journal of Pluralism under the leadership of Dr. Leonard Swindler.

Thus, in examining the role and place of Ali A. Mazrui in the operations and programs of think tanks, it would make sense to focus on how he engaged the IIIT and what specific achievements can be identified for the perplexed and the informed. Indeed, any social geographer who tries to document the man and his work must look at the journals and books of IIIT and the signatures of Ali in those documents.

Through his involvement with the American Journal of Islamic Social Sciences, Ali became first a contributor to the journal and later the editor-inchief. As a contributor, for example, he shared the literary space with younger scholars such as Muqtedar Khan who, at the time, was finishing his doctorate with Dr. John Esposito at Georgetown University. At the time, globalization was in vogue; it was at that moment when the late Samuel Huntington pushed his notion of the "clash of civilizations." Ali and the other contributors of the time published a volume on globalization in the American Journal of Islamic Social Sciences. Their exercise was a Muslim response to the orations and writings of the think tanks. It is relevant here to point out to the reader that Ali's engagement with IIIT was a part of a greater desire to counter the charges 
and counter-charges of scholars or journals seriously linked to the phenomenon of Islamophobia. In retrospect Ali Mazrui, through his own testimonies as well as the numerous Internet citations on Islamophobia and their arrows angling on Ali's intellectual face, definitely came out of this trial and tribulation with the smiling face of Khalid ibn Walid.

Besides his involvement with the journal and the annual meetings of the Association of Muslim Social Scientists (AMSS), Ali was honored for his scholarship and his deliberate efforts to link town and gown in the United States and beyond. For example, at one of the annual event of the AMSS, Ali was asked to deliver the annual lecture named after the late Ismail Faruqi. Like some of his predecessors within the AMSS, he is now off-stage; but Allah, who is the ultimate movie-maker for all times, had provided Mazrui with intellect, humor, and bridge-building skills to widen the touch of IIIT in the United States, Africa, and beyond. It was because of his links to the IIIT that Ali had serious moments with the board members and staff of the IIIT in Nigeria, Micronesia, the Middle East, and in the United States. Again, because of his intimate relations with the IIIT, Ali and his second wife, Pauline Uti from Jos, Nigeria, shared many useful moments with the leadership of the IIIT. I was present on many events where Ali presented and dialogued with colleagues and guests who are not necessarily Muslim.

In summing up this brief memorial on Professor Ali A. Mazrui, it is significant to say the following: He was the son of a chief $q \bar{a} d \bar{l}$ from Mombasa who listened to his father's lessons and performed well in Swahili as well as in English; he was a mirror of his cultural background and tried his best to be a mirror image as referenced in the widely circulated quote from the Prophet Muhammad: "Truly, we are mirrors unto each other." This dictum was his humble bearing and in his friendly relations with those who possess the Shakespearean milk of human kindness. Alhamdulillah, we call upon Allah to grant him jannah and the best He reserved for the learned and cooperative among humanity.

\section{This Issue}

We begin the first issue of 2015 with Md. Mahmudul Hasan's "English Literary Studies: Including Islamic Perspectives in Pedagogy and Practice." He focuses on some three important ways of teaching English literature in the light of Islamic teachings. They are: inculcating Islamic/moral values; identifying predominant themes and ideas inherent in literary texts and looking at them from Islamic perspectives; and reforming the curriculum. 
Next is "The Transdisciplinary Approach: A Critical Appraisal from an "Islamic Perspective" by Ali Paya. He argues that the transdisciplinary approach is not a methodology; it is rather a meta-method. Paya briefly discusses the similarities and differences between science/knowledge and technology. $\mathrm{He}$ also critically examines the views of Basarab Nicolescu, one of the most prolific proponents of a particular reading of the transdisciplinary approach. To shed more light on the potentials of the transdisciplinary approach, Paya ends with some examples form the intellectual the Islamic culture.

Rebecca Masterton follows with her "A Comparative Exploration of the Spiritual Authority of the Awliyā' in the Shi 'i and Sufi Traditions." She discusses several key aspects of walāya as they appear recorded in Shi ' $i$ hadith collections and later in one of the earliest Sunni Sufi treatises. In addition to exploring the identity of the awliy $\bar{a}$ ' and their role in relation to the Twelve Imams, Masterton also traces the reabsorption into Shi' $i$ culture of the Sufi definition of walaya, using the works of groups related to al-Dhahabi and al-Tabataba'i.

We close with "Hassan al-Turabi's Religious Discourse on Faith, Renewal, and Ijtihād" by Gubara Said Hassan and Jabal M. Buaben. They focus on Hassan A. Al-Turabi, the charismatic and pragmatic religio-political leader in the Republic of Sudan and highlight the key concepts of his religious discourse: $\bar{i} m \bar{a} n$ (faith), tajdìd (renewal), and ijtihād (rational, independent, and legal reasoning). In order to contextualize the reasoning behind his discourse, the authors try to paint a brief but informative picture of Al-Turabi's life history.

I hope that our readers will find these papers not only thought-provoking and stimulating, but also sources of inspiration and motivation for their own research. 